九州大学学術情報リポジトリ

Kyushu University Institutional Repository

\title{
A NEW SPECIES OF THE GENUS TETRAGNATHA (ARANEAE: TETRAGNATHIDAE) FROM THE BONIN ISLANDS, JAPAN
}

Okuma, Chiyoko

https://doi.org/10.5109/2417

出版情報: ESAKIA. 17，pp.141-147，1981-11-30. Entomological Laboratory，Faculty of Agriculture, Kyushu University バージョン :

権利関係 : 


\title{
A NEW SPECIES OF THE GENUS TETRAGNATHA (ARANEAE: TETRAGNATHIDAE) FROM THE BONIN ISLANDS, JAPAN
}

\author{
Снгуоко Ок и м а \\ Entomological Laboratory, Faculty of Agriculture, \\ Kyushu University, Fukuoka 812, Japan
}

\begin{abstract}
A new species, Tetragnatha boninensis, is described based on the adult spiders reared from subadults collected on the Bonin Islands of Japan. The webbingbehavior of the new species is also discussed.
\end{abstract}

Among the spiders belonging to the genus Tetragnatha, only two species, T. japonica Boesenberg et Strand, 1906 and T. laqueata L. Koch, 1871 have hitherto been known to occur on the Bonin Islands (Yaginuma, 1979). In January 1980, I had an opportunity to collect some subadult spiders of this genus on the Islands, and reared them in the laboratory to obtain the adults for identification. About one month later they grew to adults and produced their progenies, of which only a few matured in April and May of the same year.

Examining the adults, I reached to the conclusion that the species is new to science. Thus, it is described in this paper, and a note on its webbingbehavior is also given.

I wish to express my sincere gratitude to Professor Y. Hirashima and Associate Professor K. Morimoto of Kyushu University for their continuous kind guidance.

\section{Tetragnatha boninensis sp. nov.}

Male. Body length, exclusive of chelicerae, 4.0 to $4.9 \mathrm{~mm}$; carapacial length 1.75 to $1.90 \mathrm{~mm}$, width 1.05 to $1.15 \mathrm{~mm}$; abdominal length 2.5 to $3.1 \mathrm{~mm}$, width 0.9 to $1.1 \mathrm{~mm}$.

Eyes. Viewed from above, both rows moderately recurved; viewed in front, both rows nearly straight; central ocular quadrangle with posterior line wider than anterior one $(1.45: 1.20)$, slightly wider than long (1.45:1.30);

* Contribution from the Entomological Laboratory, Faculty of Agriculture, Kyushu University, Fukuoka (Ser. 3, No. 96). 
ratio of diameter of AME: ALE : PME : PLE as $100.60: 55.60: 95.60: 91.25(\mu)$; AME separated from one another by their diameter, and from ALE by about 1.5 times their diameter; PME separated from one another by about 1.5 times their diameter and is separated from PLE by about 1.5 times their diameter; lateral eyes separated from one another by diameter of ALE; AME separated from PME by slightly less than diameter of AME; height of clypeus slightly more than diameter of AME.

Chelicerae. Moderately robust, moderately divergent, length of basal segment 1.2 to $1.4 \mathrm{~mm}$; with a prolateral apophysis, a small tooth and a slanting tooth; promargin of fang groove with a not so large "large tooth" about

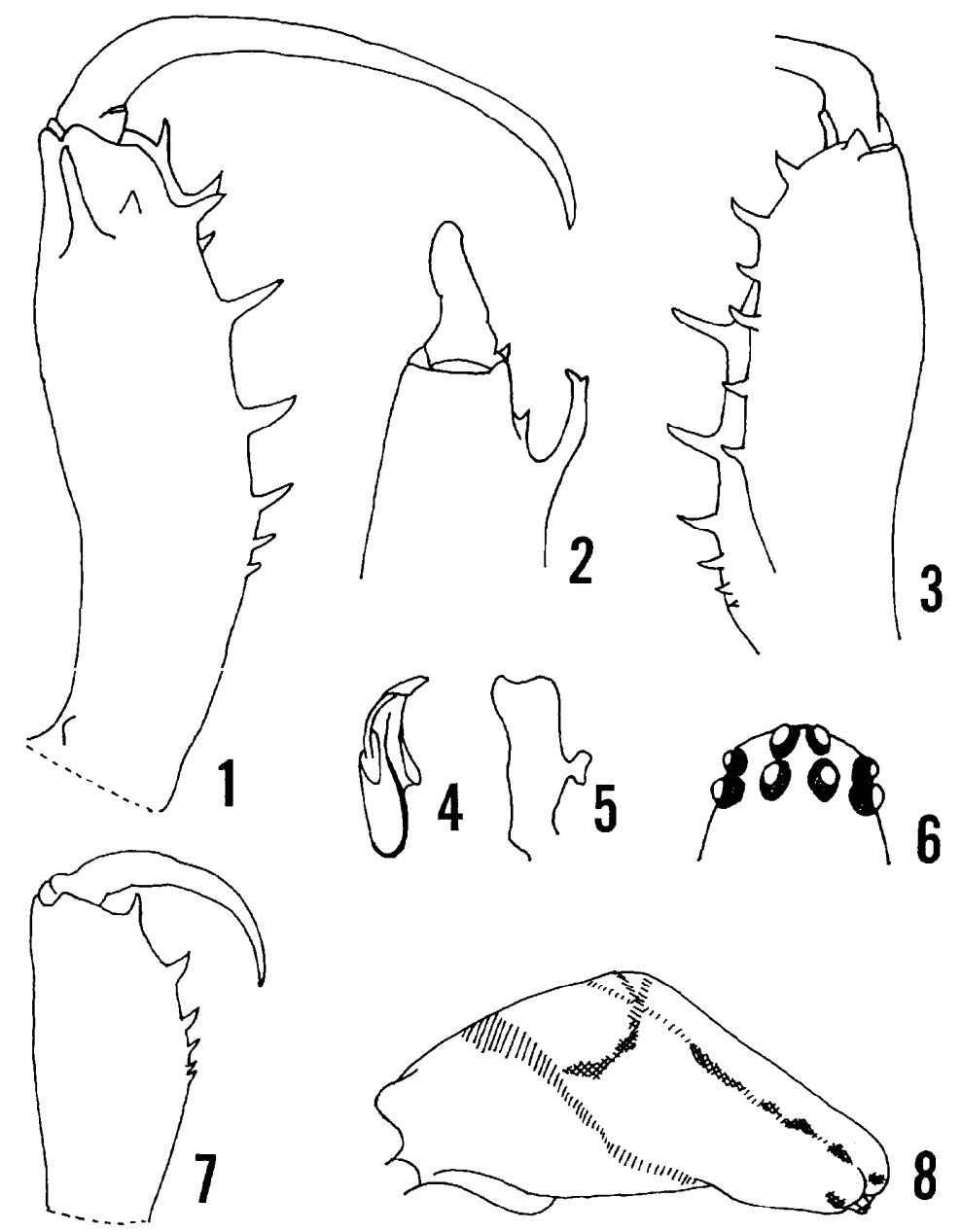

Figs. 1-8. Tetragnatha boninensis sp. nov. 1-3: Left chelicerae of male. 4: Distal end of male conductor and embolus. 5: Male paracymbium. 6: Eye group of female, dorsal view. 7: Left chelicerae of female. 8: Abdomen of female, left lateral view. 


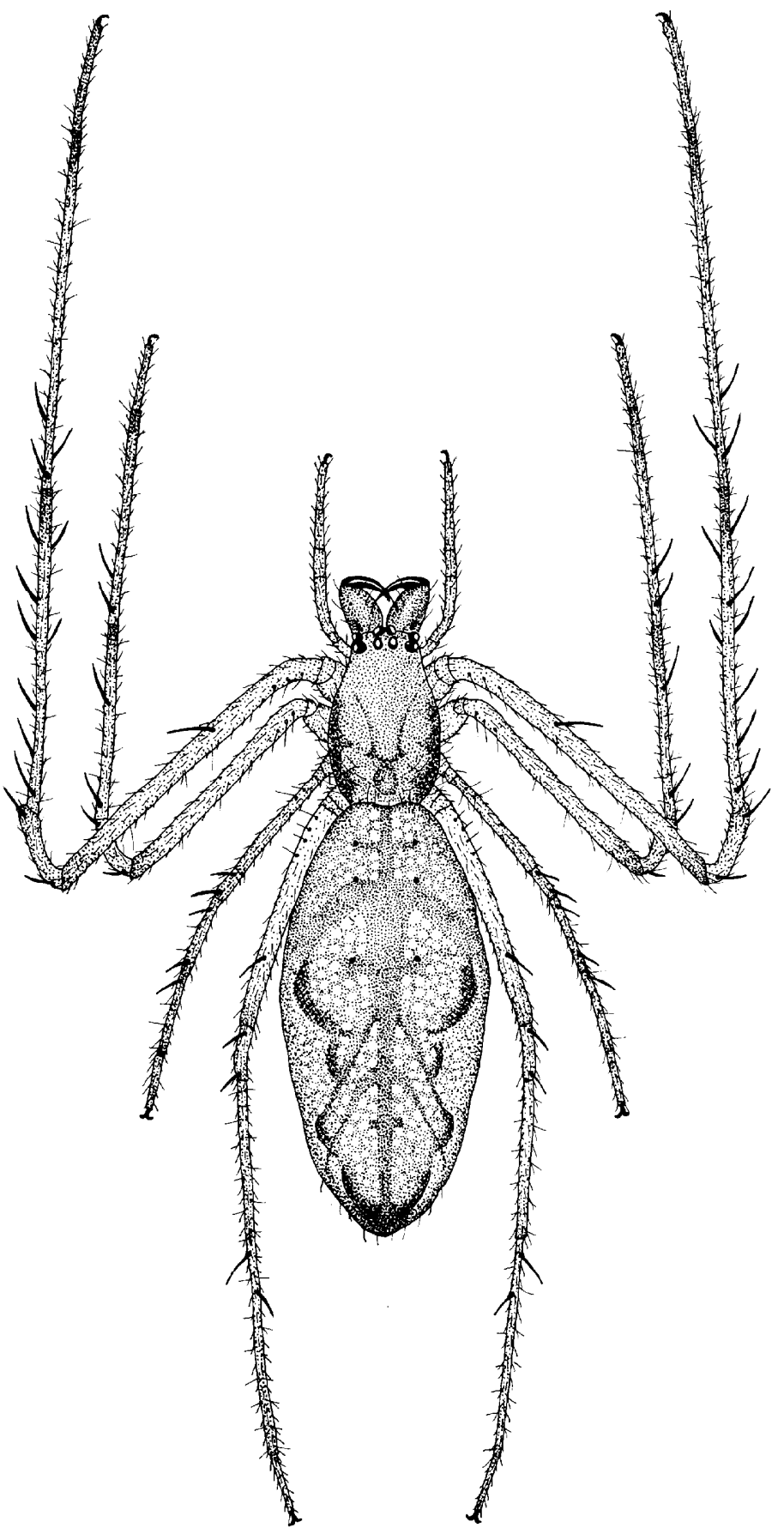

Fig. 9. Tetragnatha boninensis sp. nov., female. 
one-third from distal end; a series of five to six teeth proximal to "large tooth" diminishing in size; retromargin with a series of six teeth ; fang slightly sinuous, without particularly conspicuous features (Figs. 1-3).

Maxillae. Nearly parallel, longer than lip in ratio of $2.4: 1.0$; more than 3.7 times as long as wide at narrowest part.

Lip. Shorter than broad at base in ratio of $1.0: 1.3$; sternal suture nearly straight.

Sternum. Length 0.85 to $1.05 \mathrm{~mm}$, width 0.65 to $0.70 \mathrm{~mm}$; without conspicuous features.

Legs. 124 3. All legs with spines and hairs ; about six spines on femora legs; measurements of legs as follows :

\begin{tabular}{|c|c|c|c|c|}
\hline Femora & Patellae & Metatarsi & Tarsi & Total \\
\hline $4.76 \pm 0.69$ & $5.60 \pm 0.74$ & $5.20 \pm 0.76$ & $1.28 \pm 0.10$ & $16.85 \pm 2.27$ \\
\hline $3.33 \pm 0.43$ & $3.40 \pm 0.34$ & $3.03 \pm 0.40$ & $0.86 \pm 0.06$ & $10.64 \pm \mathbf{1 . 2 1}$ \\
\hline $1.68 \pm 0.22$ & $1.33 \pm 0.18$ & $1.30 \pm 0.18$ & $0.50 \pm 0.03$ & $4.81 \pm 0.59$ \\
\hline $3.29 \pm 0.44$ & $2.83 \pm 0.40$ & $2.79 \pm 0.49$ & 0.73 to. 05 & $9.23 \mathrm{kl} .36$ \\
\hline 0.96-t-0. 06 & $0.26 \pm 0 . \quad 03 \quad 0.43 \pm 0.03$ & - & $0.60 \pm 0.06$ & $2.25 \mathrm{f} 0.15$ \\
\hline
\end{tabular}

(All measurements in millimeters)

Palpi. Tibia longer than patella but both short; paracymbium broad; conductor twisted at the tip and both conductor and embolus closely associated (Figs. 4-5).

Abdomen. Not continued posteriorly to spinnerets, slightly extended over carapace; somewhat slenderer than in female.

Color in alcohol. Legs, palpi and chelicerae yellowish brown; carapace yellowish brown with median and marginal dusky brown stripes; maxillae, lip and sternum dusky brown; dorsum of abdomen dusky gray with indistinct markings and covered by sparse dusky yellowish spangles; venter with a central dark gray stripe.

Female. Body length, exclusive of chelicerae, 4.3 to $5.2 \mathrm{~mm}$; carapacial length 1.5 to $1.6 \mathrm{~mm}$, width 1.00 to $1.05 \mathrm{~mm}$; abdominal length 3.0 to $4.9 \mathrm{~mm}$, width 1.5 to $1.8 \mathrm{~mm}$.

Eyes. Similar to those of male ; central ocular quadrangle wider behind than in front (1.35:1. 10), about as long as broad or a little shorter than broad; ratio of diameter of AME: ALE: PME : PLE as $86.3: 50.0: 81.3: 78.1(\mu)$;AME separated from one another by slightly less than their diameter, and from ALE by 1.4 times their diameter; PME separated from one another by about 1.5 times their diameter and is separated from PLE by about 1.4 times their diameter; lateral eyes separated from one another by diameter of ALE; AME separated from PME by diameter of AME; height of clypeus slightly less than diameter of AME (Fig. 6).

Chelicerae. Length of basal segment 0.55 to $0.70 \mathrm{~mm}$; fang slightly sinuate, 
Table 1. Measurements of Tetragnatha boninensis sp. nov.

\begin{tabular}{|c|c|c|c|c|}
\hline Sex & \multicolumn{2}{|c|}{$\sigma$} & \multicolumn{2}{|c|}{ 우 } \\
\hline & Mean士s. d. & (range) & Mean土s.d. & (range) \\
\hline Body length (mm) & $4.50 \pm 0.46$ & $(4.00 \quad-4.90)$ & $4.68 \pm 0.41$ & $\left(\begin{array}{ll}4.30 & -5.20\end{array}\right)$ \\
\hline Carapace, length & $1.80 \pm 0.08$ & $(1.75-1.90)$ & $1.55 \pm 0.06$ & $(1.50-1.60)$ \\
\hline width & $1.10 \pm 0.04$ & $(1.05-1 . \quad 15)$ & $1.04 \pm 0.03$ & $(1.00-1 . \quad 05)$ \\
\hline Sternum, length & $0.94 \pm 0.09$ & $(0.85-1.05)$ & $0.83 \pm 0.03$ & $\left(\begin{array}{ll}0.80 & -0.85\end{array}\right)$ \\
\hline width & $0.69 \pm 0.03$ & (0.65-o. 70) & $0.61 \pm 0.03$ & (0.60-o. 65) \\
\hline Abdomen, length & $2.87 \pm 0.32$ & $(2.50-3.10)$ & $3.55 \pm 0.91$ & $\left(\begin{array}{ll}3.00 & -4.90\end{array}\right)$ \\
\hline width & $1.02 \pm 0.10$ & $(0.90-1 . \quad 10)$ & $1.67 \pm 0.15$ & (1. 50-1. 80) \\
\hline Chelicerae, length & $1.29 \pm 0.85$ & $(1.20-1 . \quad 40)$ & $0.61 \pm 0.06$ & $\left(\begin{array}{ll}0.55 & -0.70\end{array}\right)$ \\
\hline Maxillae, length $(\mu)$ & $675 \quad 161.20$ & $(600-750)$ & $519 \pm 31.46$ & $(475-550)$ \\
\hline width & $184 \pm 6.25$ & $(175-188)$ & $200 \pm 25.00$ & $(175-225)$ \\
\hline Lip, length & $281 \pm 12.50$ & $(275-300)$ & $250 \pm 20.40$ & $(225-275)$ \\
\hline width (base) & $378 \pm 15.60$ & $(363-400)$ & $354 \pm 23.70$ & $(338-388)$ \\
\hline Eye diameter & & & & \\
\hline $\mathrm{AME}$ & $100 \pm 5.15$ & $(95.0-107.5)$ & $86.3 \pm 2.50$ & $(82.5-87.5)$ \\
\hline A L E & $55.6 \pm 3.75$ & (50. $0-57.5)$ & $50.0 \pm 0.00$ & $(50.0)$ \\
\hline PME & $95.6 \pm 5.19$ & $(87.5-100.0)$ & $81.3 \pm 7.20$ & $\left(\begin{array}{ll}75.0 & -87.5\end{array}\right)$ \\
\hline P L E & $91.3 \pm 7.77$ & $(82.5-100.0)$ & $78.1 \pm 6.25$ & $\left(\begin{array}{ll}75.0 & -87.5\end{array}\right)$ \\
\hline
\end{tabular}

without cusps ; both margins of fang groove with five to six teeth.

Legs. $12543 . \quad$ All legs with spines and hairs; femora of first and fourth legs with one or at most two spines and those of second and third legs with one spine or absent; measurements of legs as follows :

$\begin{array}{cccccc} & \text { Femora } & \text { Patellae } \quad \text { Tibiae } & \text { Metatarsi } & \text { Tarsi } & \text { Total } \\ 1 & 2.95 \pm 0.13 & 3.45 \pm 0.11 & 3.08 \pm 0.13 & 0.94 \pm 0.05 & 10.43 \pm 0.42 \\ 2 & 1.98 \pm 0.09 & 2.10 \pm 0.07 & 1.84 \pm 0.09 & 0.66 \pm 0.03 & 6.58 \pm 0.25 \\ 3 & 1.09 \pm 0.03 & 0.95 \pm 0.04 & 0.78 \pm 0.03 & 0.44 \pm 0.03 & 3.25-1-0.09 \\ 4 & 2.09 \pm 0.06 & 1.80 \pm 0.04 & 1.78 \pm 0.05 & 0.55+0.00 & 6.21 \pm 0.15 \\ \text { Palpi } & 0.55+0.00 & 0.20+0.00 \quad 0.30+0.00 & - & 0.45 \pm 0.04 & 1.50 \pm 0.04\end{array}$

(All measurements in millimeters)

Abdomen. Somewhat swollen and gibbous just in front of median portion (Figs. S-9).

Color in alcohol. Essentially as in male but abdomen with more conspicuous spots as usual for the genus (Figs. 8-9).

Distribution: Hahajima I. of the Bonin Is., Japan.

Type material: Holotype đo (Type No. 2325, Kyushu Univ.), Hyôgidaira, Hahajima I., Bonin Is., 24. I. 1980 (matured on 22. II. 1980), C. Okuma leg. Paratypes : 1 ð and 3 우우, same data as holotype, (matured on 22-26. II. 1980) ; 
230 and 1 우, second generation of the above (matured on 10. IV.-1. V. 1980); all specimens were collected and reared by me.
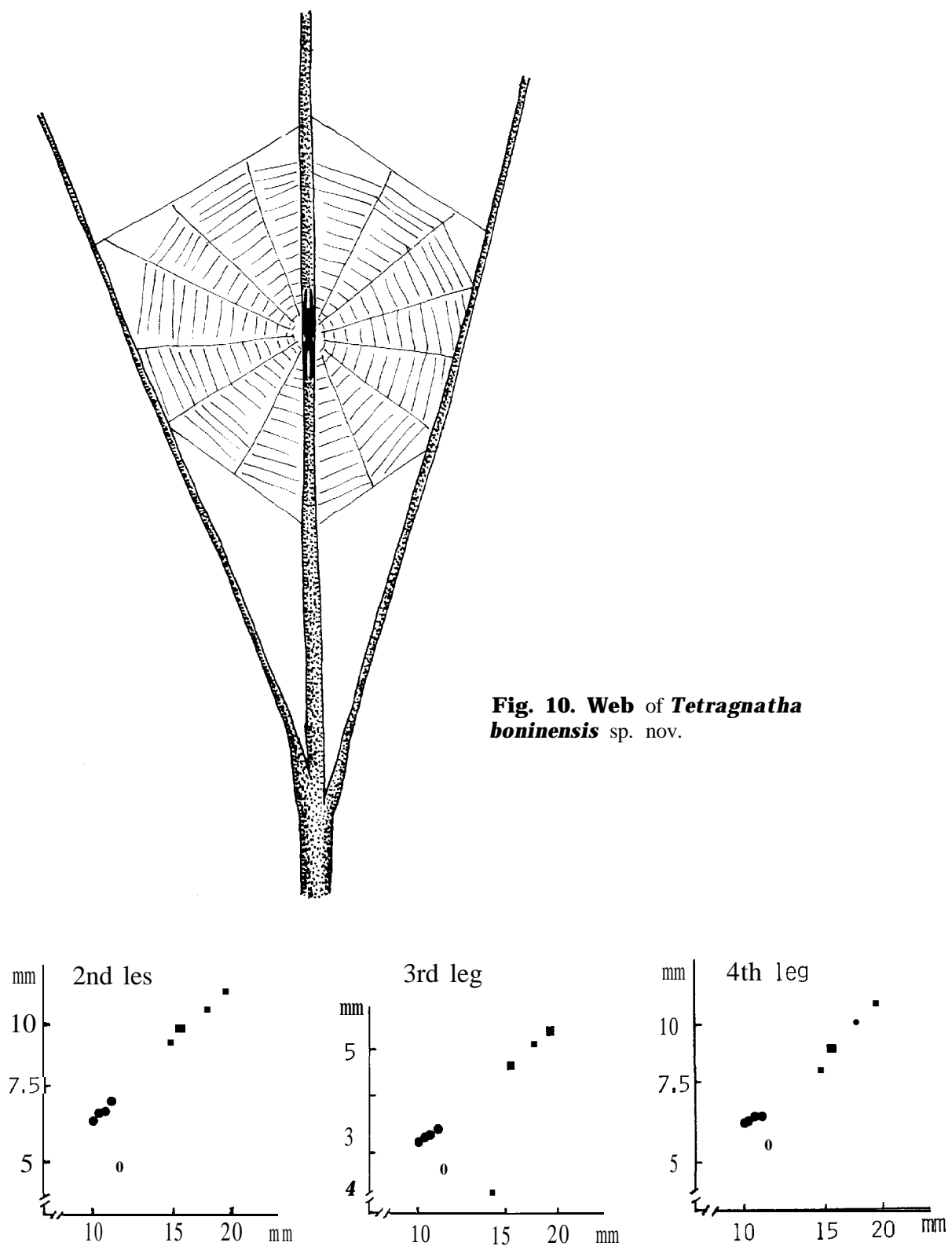

Fig. 11. Correlation of the length between the 1 st leg (the abscissa) and the 2 nd, $3 \mathrm{rd}$ and 4 th legs (the ordinate) of the two species, T. boninensis sp. nov. and T. marginata (Thorell) (from the original description) in the logarithmic scale. Black dots, T. boninensis, female; black squares, the same, male; circles, T. marginata, female. 
Webbing-behavior: The orb-webs produced by spiders of the genus Tetragnatha are, in general, located among objects such as stems or leaves of plants but the main body of the web is free from the objects. Without exception, the web of the present species was however characteristic in being supported by a stem which runs vertically the median portion of the web, as shown in Fig. 10, and, interestingly, the spider was always observed sitting on the supporting stem, at the center of the web. These webs were found on the dead plants (unidentified) of 1 . O-l. $5 \mathrm{~m}$ high which stood vertically, in the open, windy and relatively dry field of the Island. As far as I know, such a way of webbing has been noted for only three species of the genus, such as T. baculiferens Hingston in Burma (Hingston, 1927), T. ceylonica Cambridge in India (Gravely, 1921) and T. makiharai Okuma in Japan (Okuma, 1978).

REMARKS: This new species is closely related to T. marginata (Thorell, 1890) which is distributed in Australia, Burma, New Caledonia, Papua New Guinea and Seychelles, but is distinguishable from it by the unique webbing habits as mentioned above and by the difference of the relative length of the first leg to the others as shown in Fig. 11.

\section{References}

Dondale, C. D. 1966. The spider fauna (Araneida) of deciduous orchards in the Australian Capital Territory. Aus. J. Zool., 14: 1157-1192.

Gravely, F. H. 1921. Some Indian spiders of the sub-family Tetragnathinae. Rec. Ind. Mus., 22 : 423-459.

Hingston, Major R. W. G. 1927. Protective devices in spiders' snares, with a description of seven new species of orbweaving spiders. Proc.Zool.Soc. London, 18: 259-293.

Okuma, C. 1977. A new species of the genus Tetragnatha (Araneae : Tetragnathidae) from the Ryukyus, Japan. Acta arachnol., 27: 27-32.

Okuma, C. 1978. Spiders from Tsushima Is.-new records and some observations-. Heptathela, 1 (1) : 2-7. (In Japanese)

Saaristo, M. I. 1978. Spiders (Arachnida, Araneae) from the Seychelle Islands, with notes on taxonomy. Ann. Zool. Fennici, 15: 99-126.

Thorell, T. 1890. Studi sui Ragni Malesi e Papuani IV (1). Ann. Mus. Civ. Genova, 28: 1419.

Yaginuma, T. 1979. Spiders of the Bonin Islands, Japan. Nat. and Anim., 9 (8) : 33-36. (In Japanese) 